\title{
Farm size and volume of external transportation services at selected farm businesses
}

\author{
Stanisław Kokoszka ${ }^{1, *}$, and Zbigniew Daniel $^{1}$ \\ ${ }^{1}$ Department of Production Management and Applied Computer Science, Balicka 116B, 30-149 Kraków, Poland
}

\begin{abstract}
The present survey and data analysis confirmed the impact of the farm size (based on the Utilized Agricultural Area) on the volume of external transportation services despite the overall improvement of owned means of transport. The main transport characteristic, i.e. shipment distance increases with the farm size. Hence, the largest farm businesses characterized by higher commercial outputs use external transportation services to a greater extent although they own better quality and higher number of farm vehicles. At the average freight volume transported by external services of 4.37 tons per hectare of the Utilized Agricultural Area, the share of contracted transportation services in the total freight transport increases from $13.95 \%$ in the smallest farms to $28.42 \%$ in the largest farm businesses. This analysis was confirmed by the correlation analysis between the farm size and volume of external transportation services.
\end{abstract}

\section{Introduction}

Due to continuous growth of commercial agricultural production, farm businesses are forced to unwillingly become transportation businesses. Thus, transportation costs decisively contribute to profitability of production $[1,3,10]$. Minimization of transportation costs depends, among other things, on transport provision methods, including the use of transportation services. In fact, production services for agriculture are a component of the modern agriculture sector and belong to efficient means of overcoming the opposition between consequences of scientific and technical progress and costs of its implementation [2, 5, 7, 11]. According to Tabor et al. [6] farms better equipped in technical means of production show a limited need for technical services. At the same time, often the lack of necessary equipment, time saving and in many cases, according to farmers, lower costs induce to contract external services [2,4].

According to our previous studies [4, 8, 9], in southern Poland, $59.04 \%$ of farm businesses engaged in commercial production responded that transportation services were needed, of which $48.80-68.18 \%$ already contracted those services while $29.51-72.73 \%$ provided transportation services as a way of increasing their income.

\section{Scope and aim of the study}

The aim of the study was to assess the volume of external services contracted by farm businesses in relation to the farm size (based on the Utilized Agricultural Area (UAA)). The studies and analyses were undertaken to determine whether transportation services for agriculture (farm businesses) are needed and to estimate their level.

The survey was conducted in 653 farm businesses located in 21 municipalities of southern voivodeships (Małopolskie, Podkarpackie, Świętokrzyskie, Śląskie). The survey included all transport activities carried out in these farms. Farms contracting transportation services either to transport businesses or to neighbors were selected for the study. The analyzed group of farm businesses represented $35.22 \%$ of the whole population of farms surveyed. It should be mentioned that of the whole sample of farms contracting services, $37 \%$ also provided services, however, $100 \%$ of them provided services to their neighbors either as the "payment in work" or as an additional source of income.

\section{Methodology}

The survey was carried out via a guided survey regarding most of all transport activities. The first part of the survey was related to general characteristics of the farm (the structure of land use, structure of sowing, stocking density, structure and volume of production), the second part regarded farm vehicles and their use and the third part was related to working conditions of transport means and the use of transportation services (transport volume, service provider, motivation of contracting transportation services).

Based on the obtained data, the total freight transport volumes and share of external transportation services were determined and related to the farm size. The surveyed farms were divided into 3 groups depending on UAA:

- $<10$ UAA hectares $-50.43 \%$, in UAA - $20.67 \%$ 
- 10.01 do 20.00 UAA hectares - $30.87 \%$, in UAA $32.98 \%$

- > 20.01 UAA hectares $-18.70 \%$, in UAA - $46.35 \%$

\section{Sample and study results}

The survey sample comprised 230 farm businesses located in southern voivodeships. The surveyed farms represented different segments of agricultural sector from general non-specialized agricultural production to specialized agribusinesses in potato, vegetable, milk or fruit segments. Thus, cargo types, freight volumes and payload per trip vary widely. The freight volume averages 32.42 tons per hectare of UAA ranging from 4.73 do 221.75 .

The second major transport characteristic, i.e. shipment distance is equally variable. Basic characteristics of the studied farms relevant to transportation are presented in Table 1.

Table 1. Selected characteristics of surveyed farms.

\begin{tabular}{|c|c|c|c|c|c|}
\hline \multirow{2}{*}{\multicolumn{2}{|c|}{ Characteristics }} & \multirow{2}{*}{$\begin{array}{c}\text { Whole } \\
\text { sample }\end{array}$} & \multicolumn{3}{|c|}{ UAA grou } \\
\hline & & & \multirow{2}{*}{\begin{tabular}{|c|}
$\begin{array}{c}<\mathbf{1 0} \text { ha } \\
\text { UAA }\end{array}$ \\
5,76
\end{tabular}} & \multirow{2}{*}{\begin{tabular}{|c|}
$\mathbf{1 0 . 1 -}$ \\
$\mathbf{2 0}$ \\
ha \\
UAA \\
15,01
\end{tabular}} & \multirow{3}{*}{$\begin{array}{c}\begin{array}{c}>\mathbf{2 0} \text { ha } \\
\text { UAA }\end{array} \\
34.84 \\
\end{array}$} \\
\hline \multirow{4}{*}{$\begin{array}{l}\text { Utilized } \\
\text { Agricultural } \\
\text { Area (ha) }\end{array}$} & & & & & \\
\hline & & & & & \\
\hline & $\min$. & 80 & 80 & & 20.0 \\
\hline & max. & & 10.00 & & 155.0 \\
\hline \multirow{3}{*}{$\begin{array}{l}\text { Average } \\
\text { shipment } \\
\text { distance }(\mathrm{km})\end{array}$} & $\Delta \mathrm{VG}$ & & 32 & & 7.2 \\
\hline & min. & & 06 & & \\
\hline & max. & 157 & 31.71 & 41.57 & 31.5 \\
\hline \multirow{3}{*}{$\begin{array}{l}\text { Number of } \\
\text { vehicles per } \\
\text { farm }\end{array}$} & $\mathrm{AVG}$ & & 31 & & 4.3 \\
\hline & min. & & 00 & & \\
\hline & max. & 0.00 & 6.00 & 10 & \\
\hline \multirow{3}{*}{$\begin{array}{l}\text { Average } \\
\text { vehicle } \\
\text { payload (tons) }\end{array}$} & AVG & & 2.57 & & 3.5 \\
\hline & min. & 0.50 & 0.50 & 1.0 & 2.0 \\
\hline & max. & & 00 & & 9.0 \\
\hline \multirow{3}{*}{$\begin{array}{l}\text { Share of cars in } \\
\text { equipment }(\%)\end{array}$} & AVG. & & 18 & & 8.7 \\
\hline & min. & & 0.00 & & 0.0 \\
\hline & $\max$ & & 0.00 & & 0.0 \\
\hline \multirow{3}{*}{$\begin{array}{l}\text { Share of } \\
\text { transportation } \\
\text { services (\%) }\end{array}$} & $\mathrm{AVG}$ & & 23.89 & 31.73 & 40.91 \\
\hline & min. & & 1.20 & & 4.12 \\
\hline & max. & 87.82 & 59.83 & 87.82 & 83.5 \\
\hline \multirow{3}{*}{$\begin{array}{l}\text { Sales } \\
\text { (tons per UAA } \\
\text { hectare) }\end{array}$} & AVG & & 4.73 & 38 & 11.53 \\
\hline & min. & & 0.00 & 0.00 & 7.7 \\
\hline & max. & 47.33 & 45.82 & 32.88 & 47.3 \\
\hline
\end{tabular}

At the average farm area of 14.05 UAA hectares, variability in the studied group is very high and ranges from the minimum of 0.80 hectares to the maximum of 155.0 hectares which means that the largest farm has 193 times greater UAA than the smallest one. The largest farms classified into the group $>20$ UAA hectares are on the average 2.3 times bigger compared to the medium group (10.1-20 UAA hectares) and almost 6 times bigger than the smallest ones ( $<10$ UAA hectares). The average shipment distance is linked to the farm size. The shipment distance averages $5.70 \mathrm{~km}$ for the whole sample, ranging from 4.32 for the smallest farms to $7.20 \mathrm{~km}$ for the largest farm businesses, which means almost $167 \%$ rise. It results not only from the increased shipment distance in internal transport (due to a larger farm area) but also from the external transport. Larger farms generate a greater freight volume resulting from higher output, and they search for more price-efficient markets which is most often connected with the increasing shipment distance. At the same time, variability of the basic transport characteristic, i. e. shipment distance is very wide also in all UAA groups. The average variability range is from the minimum of $0.06 \mathrm{~km}$ to the maximum of $41.57 \mathrm{~km}$, thus, the difference in the shipment distance between the farm with the most advantageous location in relation to fields and upstream and downstream markets and the farm with the least advantageous location is $6928 \%$. This fact in connection with the freight volume indicates a diverse burden of transport in farm businesses. Likewise, equipment of farm business in transport means, decisive for efficient transportation, vary both within and between the UAA groups On average, the surveyed farm businesses own and operate 3.02 vehicles ranging from 1 to 10 vehicles. The number of owned vehicles increases with the farm size. Specifically, the increase in the farm size between UAA groups by almost $600 \%$ resulted in a rise in the number of vehicles per farm by $187 \%$. It indicates that considerable differences in the above parameters are most probably the effect of increased efficiency of farm vehicles in the biggest farm businesses. This is confirmed by a much better quality of transport means in the largest farm businesses as estimated based on the average payload of a vehicle which averages $2.57 \mathrm{t}$ in the smallest farms businesses and $3.54 \mathrm{t}$ in the largest ones. In this aspect, it is also beneficial that the share of vehicles with higher efficiency (i.e. trucks) grows with the farm size. The largest farms own over 2 times heavier vehicles than the smallest ones. The next factor that can significantly contribute to contracting transportation services is related to the share of outer transport in the total transport volume. Transportation services are more often contracted for outer transport over longer distances in much better conditions frequently during the off season. Their share in total transport volumes is also significantly influenced by the level of commercial production related, among other things, to the farm size. This view is confirmed by the increase in the share of transportation services with the farm size. Specifically, the share of transportation services averages $29.49 \%$ of the total transport volumes for the whole study sample and increases from $23.89 \%$ in the smallest farms to $40.91 \%$ in the largest UAA group. However, variability within the UAA groups is very high. The share of external transport in the total transport volume is the effect of sold production (tons) and impacts on transport volume but also on demand for 
transportation services which sometimes, depending on the cargo type, require specialized equipment. The freight volume related to the sold production clearly increases with the farm size. It averages 7.13 tons per hectare of the UAA and increases by ca. $244 \%$ between the smallest and the largest farms. The results of this analysis are presented in Tab. 2 showing the volume of transportation services and their share in the total transport volume.

Table 2. Volume of transportation services.

\begin{tabular}{|c|c|c|c|c|c|}
\hline \multirow{2}{*}{\multicolumn{2}{|c|}{ Characteristics }} & \multirow{3}{*}{$\begin{array}{r}\begin{array}{r}\text { Whole } \\
\text { sample }\end{array} \\
4.37 \\
\end{array}$} & \multicolumn{3}{|c|}{ UAA group } \\
\hline & & & $\begin{array}{c}<10 \\
\text { ha } \\
\text { UAA } \\
\end{array}$ & \multirow{2}{*}{\begin{tabular}{|c|}
$\begin{array}{c}10.1-20 \\
\text { ha } \\
\text { UAA }\end{array}$ \\
5.01
\end{tabular}} & \multirow{2}{*}{\begin{tabular}{|r|}
$\mathbf{2 0}$ ha \\
UAA \\
6.51 \\
\end{tabular}} \\
\hline \multirow{3}{*}{$\begin{array}{l}\text { Freight volume } \\
\text { (tons per hectare } \\
\text { of UAA) }\end{array}$} & AVG. & & 3.20 & & \\
\hline & $\min$. & 0.10 & 0.10 & 0.19 & 0.29 \\
\hline & $\max$. & 14.94 & 14.43 & 14.94 & 8.69 \\
\hline \multirow{3}{*}{$\begin{array}{l}\text { Share of } \\
\text { transportation } \\
\text { services }(\%)\end{array}$} & $\mathrm{AVG}$ & 18.02 & 13.96 & 18.35 & 28.42 \\
\hline & $\min$. & 0.11 & 0.11 & 0.64 & 0.66 \\
\hline & $\max$. & 68.22 & 54.25 & 51.79 & 68.22 \\
\hline \multirow{3}{*}{$\begin{array}{l}\text { Shipment } \\
\text { distance }(\mathrm{km})\end{array}$} & AVG & 14.18 & 10.47 & 18.52 & 17.00 \\
\hline & min. & 1.40 & 1.00 & 0.60 & 7.10 \\
\hline & $\max$. & 100.00 & 80.00 & 120.00 & 100.00 \\
\hline
\end{tabular}

Data presented in Table 2 confirm the view that the largest farm businesses characterized by the highest commercial output to a greater extent use external services although they are equipped with better quality farm vehicles and their higher number.

The average freight volume transported by external transportation services is 4.37 tons per hectare of UAA and ranges in the UAA groups from 3.20 to 6.51 tons per hectare of the UAA. Despite the increase in the total transport volumes in farm businesses, resulting from a larger area, the share of transportation services in the total transport volumes rises from $13.96 \%$ in the smallest farms to $28.42 \%$ in the largest farm businesses. However, it should be emphasized that the variability of the share of transportation services in the total transport volumes is extensive both when the whole sample is concerned and when the UAA groups are analyzed separately. It appears that the main cause of contracting transportation services by a farm business is related to the shipment distance resulting from locations of upstream and downstream markets. This can be corroborated by the difference between the average shipment distance in all farm businesses surveyed, i.e. $5.70 \mathrm{~km}$ and the shipment distance for transportation services averaging $14.18 \mathrm{~km}$, thus the difference is almost $250 \%$. In addition, the maximum shipment distance for external transportation services reaches 100 $-120 \mathrm{~km}$ while the respective value for own farm vehicles (without services) is ca. $40 \mathrm{~km}$.

At the final stage of analysis, the effect of farm size on the volume of contracted transportation services was estimated. A relationship between the independent variable (farm size) and dependent variable (the volume of contracted services) is presented in Figure 1.

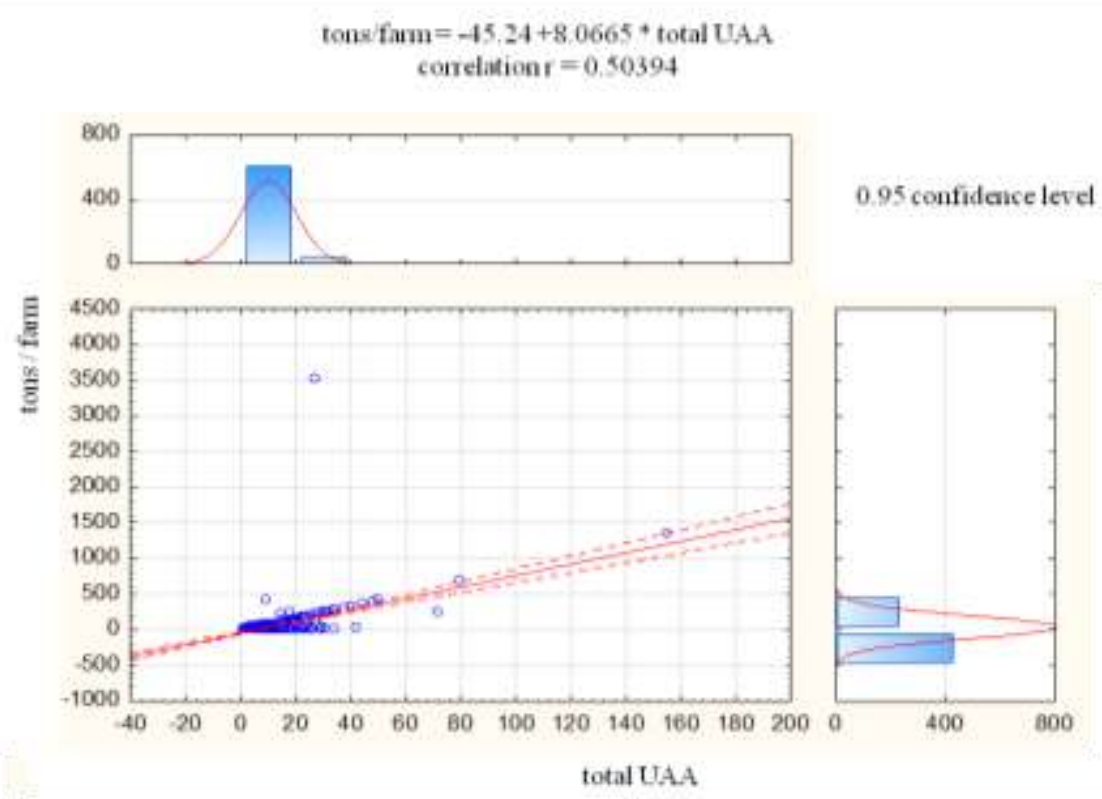

Fig.1 Effect of farm size (UAA hectares) on volume of transportation services (tons) per one hectare of UAA.

At the correlation coefficient of 0.50394 and significance level of 0.05 , the equation of the relationship between the farm size in the UAA and volume of transportation services (freight tons) assumes the form:

$$
U t r=-45,24+8,0665 \cdot P_{U R}
$$

where:

Utr - volume of transportation services in tons $\mathrm{P}_{\mathrm{UR}}$ - utilized agricultural area (UAA hectares)) 
The above equation can be used for forecasting the demand for transportation services based on the freight volume per hectare of the UAA in farm businesses with the area ranging from 0.8 to 155 UAA hectares. According to the equation (1), transportation services will be contracted by farm businesses larger than 5.61 UAA hectares and they will amount to 0.013 tons. Farm business with 155 UAA hectares will use external services to transport 1205 tons.

\section{Summary and conclusions}

Owned farm transport means, considerably influencing the use of transportation services, show improvement with the increasing farm size, especially in terms of the vehicle quality (payload of a vehicle). However, the basic transport characteristic i.e. shipment distance increases with the farm size which is disadvantageous. Thus, the largest farm businesses characterized by higher commercial production to a greater extent use external transportation services although they are equipped with better quality and higher number of farm vehicles owned. Specifically, the average transport volume carried by transportation services is 4.37 tons per UAA hectare ranging from 3.20 to 6.51 tons per UAA hectare. The share of transportation services in the total transport volumes increases from $13.96 \%$ in the smallest farms to $28.42 \%$ in the largest farm businesses. The presented values can result from the difference in the average shipment distance of $5.70 \mathrm{~km}$ and shipment distance for external services averaging $14.18 \mathrm{~km}$, thus these values differ by $250 \%$. The presented analyses confirm that the demand for transportation services increases with the farm size.

\section{References}

1. J. Bielejec, Transport rolniczy, (IBMER, Warszawa, s.1-220, 2001)

2. R. Jabłonka, K Kapela, Inżynieria Rolnicza, 1(119) (2010)

3. S. Kokoszka, M. Kuboń, S. Roczkowska-Chmaj, J Borcz, Analiza $i$ uwarunkowania rynku ustug $i$ urzązeń $w$ transporcie wiejskim (PTIR Kraków, 2001)

4. S. Kokoszka, Journal of Reseaarch and Applications in Agricultural Engineering, Vol. 58(2) (2013)

5. S. Tabor, Inżynieria Rolnicza, 10(85) (2006)

6. S. Tabor, M Kuboń, Inżynieria Rolnicza, 7(125) (2010)

7. T. Szuk, Inżynieria Rolnicza, 8(117) (2009)

8. S. Kokoszka, S. Tabor, Journal of Reseaarch and Applications in Agricultural Engineering, Vol. 61(1) (2016)

9. S. Kokoszka, S. Tabor, Journal of Reseaarch and Applications in Agricultural Engineering, Vol. 62(1) (2017)

10. D. Gollin, R. Rogerson, Journal of Development Economics, 107 (2014)
11. S. Kallas, Launch of the Green Freight Europe Initiative - Speech 12/230 (2012) 